\title{
Adam, B., Magdalena, K. \& Maciej, S. (Eds.). (2018). Borders and Beyond: Orient-Occident Crossings in Literature. Malaga: Vernon Press. 282 pages. (ISBN: 978-1-62273-383-5)
}

Khedidja CHERGUI ${ }^{1}$ (])

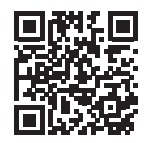

${ }^{1}$ Assistant Lecturer, Ecole Normale Supérieure de Bouzareah, Department of English, Algiers, Algeria

ORCID: K.C. 0000-0002-5644-7376

\section{Corresponding author:}

Khedidja CHERGUI,

Ecole Normale Supérieure de Bouzareah,

Department of English, Algiers, Algeria

E-mail: chergui.english88@gmail.com

Submitted: 01.09.2020

Accepted: 26.10 .2020

Citation: Chergui, K. (2020). Borders and Beyond: Orient-Occident Crossings in Literature [Review of the book Borders and Beyond: Orient-Occident Crossings in Literature, by Adam Bednarczyk, Magdalena Kubarek, Maciej Szatkowski]. Litera, 30(2), 803-808. https://doi.org/10.26650/LITERA2020-0109

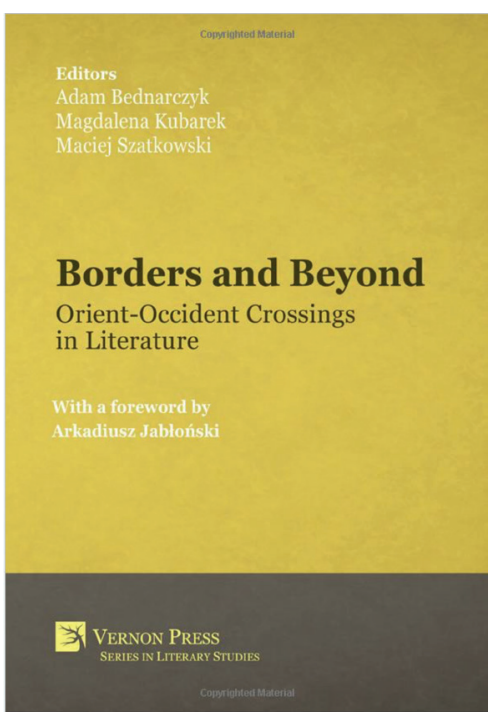

Borders and Beyond: Orient-Occident Crossings in Literature fills a gap in literature already generated on the representations of border and border crossings in literature and theory. With an interdisciplinary approach, Borders and Beyond covers a sequence of research articles which bring together a number of insights on the Orient-Occident crossings in literature, art, religion, ethics and history. Framed with some theoretical 
insights like Edward Said's Orientalism, deorientalism, intertextuality, hybridity, postcolonialism, and otherness, the writers in this volume, with a fluidity of perspective, break away from the usual and perpetuated Eurocentric approaches to literature and present, and take on, instead, a diversified eclectic tradition of viewing/reading and writing literary texts, an initiative which takes us back and forth from Europe to China, Japan, the Arab World, Turkey, Turkmenistan in a manner that defies the center and periphery rhetoric. This volume is divided into five broad parts with each part composing of a number of essays which fall within a common thread of interest.

The first part, Limitations and Borderlands in Oriental Poetry (pp. 1-46) consists of three essays which weave together different literary experiences of border-crossing or transgression which cut across different geographies. Muneerah Bader Almahasheer's "Adaptations and Evocations of Orientalism in Nāzik al-Malā'ika's Poetry" and through situating the poetry of Nāzik al-Malāika, who was a western trained Middle Eastern Iraqi poet, in an orientalism-deorientalism dialectic, questions whether her poetry could survive the deorientalising rhetoric through border crossing between the Arab and western cultures and the cultural transgressions associated with this experience. A similar exploration of how Orientalism is reversed through intersection and intertextuality is manifested in Mohammad Amin Mozaheb's paper "An In-depth Comparative Study of Victor Hugo and Shahriar's Poetry" which reflects, in a comparative manner, upon the poems written by Shahriar and Hugo in view of their treatment of God and religion pointing out similarities and differences between the Catholic and Muslim Gods. Daniela Zhang Cziráková's "Crossing Borders in the Opposite Direction: An Influence of Western Elements in Contemporary Chinese Poetry" insightfully takes this reversal of border crossing a step further through exploring the influence of the Western canon and poetics on Chinese poets and artists. Daniela, translating the poems herself for the international festival of poetry Ars Poetica in Bratislava, sketches through the poetry of four Chinese poets, Chen Dongdong, Song Lin, Tang Xiaodu and Zhao Si, whose poetry she thinks of as a literary attempt to "combine modernism and original Chinese tradition" and where Western influence is "transparent not only in the structure of language, in the way of using metaphors, but sometimes even in using specific names of geographical places or names of people" as she thinks that their poems "bear stronger features of the West, visible in using Western localities" (p. 37). Daniela points out cross-cultural and universal annotations as both implicitly and explicitly evinced in poems like In the Boulogne Forest, Rose Garden and I cry out your name. 
While the first part looks at border crossing as mostly manifest through literary intertextuality and technique, the second part of the book, Literary Boundaries Ethical Limitations: Classical Literatures of the Orient (pp. 47-82) sheds more light on the ethical aspect of such border crossing as inspired by the classical Arab and Japanese poetic traditions. The first essay, "Borderlines of Morality: Exploring the Ethos of the Mu'allaqa" by Zane Šteinmane looks at the pre-Islamic and $8^{\text {th }}$ century collected anthology of poetry and tries to reveal the moral ideas and values of ancient Arabia as communicated by each of the anthology's seven poets. According to the writer, this collection of poems was an attempt at unveiling the Pre-Islamic Arabic desert identity through emphasizing "the Bedouin concepts of honor" (p. 51). With a matching tone, Arzu Sadykhova's essay on "The Case of Love Stories about Poets of Bedouins" shares Zane's thematic concern where it compares a number of Arab romantic anthologies at the aesthetic, structural and functional levels. Adam Bednarczyk, in his essay Poetic Souvenirs: The Meaning of Ise Monogatari in Sōkyū's Miyako no Tsuto goes on with this task of showcasing the negotiation of the classical and the modern and beautifully reads through classical Japanese priest Sōkyū's travel account titled Miyako no Tsuto (Souvenir for the Capital, c. 1352) in view of highlighting the "role and significance of intertextual references to ancient works in order to show (un)changing the perception of utamakura" (p. 70). The author reminds us that Sōkyū and some of his contemporary diarists thought of poetry as an outlet to the human soul and secret desires, and a means to attain a 'state of enlightenment'.

The third part of this collection, Orient-Occident Historical and Social Borders in Literature (pp. 83-150) carries further insights on border crossing in literature with a particular focus on the narrative form. For instance, while Tetiana Derezhytska's "The "East-West" Dichotomy in the English Modernist Novel" takes an imagological perspective in reading the novels of Leonard Woolf and Edward Forster in view to show the "functional revelation of the textual and contextual aspects" in both writers' novels with a focus on their "discursive constructions of auto- and hetero-images" (85), Olivier Harenda's "The Boundaries of Historical Accuracy: Contemporary Rereading of Salman Rushdie's Midnight's Children" concentrates rather on the intersection of the historical reality, post-colonialism and magic realism in Rushdie's fiction. Harenda's analysis draws parallels between Rushdie's Midnight's Children and some of India's major historical events like the Partition of 1947 and the State of Emergency of 1975. The writer's analysis targets also the way Rushdie treats Midnight's Children as the Lost Generation of India and his criticism of India's political 
discourse through the figure of the then Prime Minister, Indira Gandhi. The analysis points out to the fact that the new political and historical realities in India might make any attempt at rereading or reinterpreting Rushdie's novel prone to certain historical inaccuracies. With a different perspective and within a different context, Magdalena Kubarek's “Between Literature and Ideology: Ad-da'wa Al-Islāmiyya in the novels by Nağīb Al-Kaylānī" discusses how literature is put in the service of ad-da'wa (Arabic for spreading faith or religious propaganda) in the Islamic context. Magdalena thinks that this ad-da'wa literature, mainly since the 1980s, aims to defend Islamic values against the influence of the West. Taking Naǧỉb Al-Kaylānī's, who is considered a pioneer for the genre, Islamic novels as an epitome in this context, the writer pays specific attention to his Contemporary Islamic Novels series which situate, according to the writer, the Islamic societies portrayed amidst the warring worlds of "imperialism, communism, and Zionism" (p. 103).

The book's fourth part, Crossing Borders in Travel: Journey in Oriental Literature and Inspired by Orient introduces a more specific reading into border crossings in literature which transcends characterization to lay more focus on the traveller's experience of the border and its aspects in travel writing. Tomasz Ewertowski in his "The Great Wall of China in Polish and Serbian Travel Writing (From the 18th until the Middle of the 20th Century)" presents new insights on how the Great Wall of China and the myths surrounding it were viewed and interpreted from a non-Chinese perspective through highlighting the experiences of the Polish and Serbian travellers who visited China in the period from the 18th century until the middle of the 20th century. Because travel writing is considered, according to the writer, as both a production and dissemination of knowledge, the Serb and Polish travelogues are portrayed in an in-between mood of sympathy and ambivalence towards what they think of as a historical myth. Thinking of these travellers as both diplomats and reporters, Tomasz points to the fact that each of the authors' account is driven by his romantic sensibility and intellectual background among other things.

Different from the Great Wall of China and the way it was portrayed in western travel writing, Magdalena Lewicka's essay "Ar-Riḥla in the Service of An-Nahḍa: Rifā 'a aț-Ṭahțāwī's Concept of Crossing Geographical and Cultural Boundaries" and after a vivid account of the adab ar-riḥlāt (Arabic travel literature) and its religiously, politically and economically motivated development since the 9th century which mobilized the Arabs' travel instinct from the pilgrimage to Mecca, to other 
metropolises such as Baghdad, Damascus, Jerusalem, Cairo and Tunis, the writer focuses on the Egyptian novelist Rifā'a aț-Ṭahțāwī's account of his stay in Paris and how his westward journey opened the door to a series of Orient-Occident confrontations: between the West and the Muslim world, between Paris and his native Egypt and within a western supremacist philosophy which treats the Orient as a fantasy inspired abstract construct. As one of the voices of nineteenth-century Arab Nahḍa or Renaissance, Rifā‘a aț-Ṭahțāwī's fiction attempts to, according to the writer, present "the political, social, cultural and educational institutions that he encountered in Paris and regarded as a model worth replicating in his homeland" (p.176). Małgorzata Sokołowicz's essay "Crossing the Borders of Decency: Gustave Flaubert, Maxime Du Camp and their Oriental Journey", in contrast, works the other way around presenting an Occident's journey to the Orient which was mostly motivated by Man's fantasy and erotic impulses. Flaubert's fascination with Egypt and the way he wrote about its baths, brothels, homoerotic sex and openly satisfied desires changed his perspective of sensual desire as perceived in his homeland viewing it as more enclosed and conservative compared to what he experienced in Egypt. Whether yielding to fantasy or real experience, the image of the Orient in Flaubert's texts, like many others, perpetuates previous stereotypes generated by European travellers in the Middle East or the Arab world.

The Book's last part titled Multidimensionality of Cultural, Social and Emotional Borders in Oriental Literature (pp. 200-256) presents border crossing within one's personal universe and one's textual abode. Milica Obrenović's "The World of Haruki Murakami- a Hidden World of Ourselves" transfers us to the world of the iconic Japanese writer Haruki Murakami who, through his delicate approach to his characters' domestic, psychological and romantic lives, shakes our sensibilities towards the inner and private realms of his characters. Milica thinks that Haruki "creates quite genuine characters, with whom we can not only easily identify, but also empathise," (p. 202) and that we, as readers, end up sharing his characters inner fears, fantasies, desires, beauty and insecurities. We end up crossing the border from our world to the world he creates for his characters regardless of geographical or cultural background. Equally taking us to the world of other private universes, Olga Nowicka's essay, "Crossing Boundaries: From Private to Public Spaces: Memoirs of Antarjanam" presents us with the experience of the Nambudiri women, who are traditionally called antarjanams (literally: the indoor people) in crossing the boundaries from the private to the public circles. Supporting her analysis with some 
social facts and recounted memoirs, Olga argues that reformist movements and calls for change participated immensely in helping the antarjanams step out of their indoor lives to a world of possibilities and freedom.

In a world blighted by xenophobia, lack of intercultural dialogue, violence and religiously distasteful manners, Borders and Beyond: Orient-Occident Crossings in Literature makes a further step towards cross-cultural literacy. The essays in the present volume, indeed, offer rich layers of analysis and literary interpretation which can help us understand, to a large extent, border crossings in literature and offer a great opportunity for the students and researchers with interest in Orient-Occident critical tradition, intertextuality and literary criticism to lay the ground for their research in any of the areas discussed in the volume.

\section{Reference}

Adam, B., Magdalena, K. \& Maciej, S. (Eds.). (2018). Borders and Beyond: Orient-Occident Crossings in Literature. Malaga: Vernon Press. 